\title{
The Secondary Mortgage Market in the USA: Features and Structure
}

\author{
Viktor F. Ponka ${ }^{1}$ \\ ${ }^{1}$ Peoples' Friendship University of Russia, Russian Federation \\ Correspondence: Viktor F. Ponka, Department of Civil and Labor Law, Peoples' Friendship University of Russia, \\ Russian Federation. E-mail: vfponka@mail.ru
}

Received: May 25, 2015 Accepted: July 23, 2015 Online Published: August 16, 2015

doi:10.5539/ass.v11n24p224 URL: http://dx.doi.org/10.5539/ass.v11n24p224

\begin{abstract}
In the present article author explores characteristics and structure of the secondary mortgage market of the United States of America. The study begins with the history of the development of the market. Thus, the author notes that the practice of issuing securities backed by mortgage assets stared with the work of "Ginnie Mae". Such refinancing helped to provide "Fannie Mae," and then began the development of the turnover of securities, backed by pools of mortgages. Further the author considers: 1. the main features of the securities issued by mortgage institutions; 2. "Fannie Mae": the main types of equity securities (debt instruments); 3. "Fannie Mae": the purchase of mortgage loans on the free market system; 4. Tandem program; 5. Conduits: non-governmental mortgage organizations. In conclusion, the author infers that the experience of the USA arouses the particular interest. Since 1970, the United States achieved significant results and laid the foundation for the economic development of the USA.
\end{abstract}

Keywords: mortgage, USA, sphere, financial system, practice, market, securities

\section{Introduction}

United States is about "half the size of Russia; about three-tenths the size of Africa; about half the size of South America (or slightly larger than Brazil); slightly larger than China; more than twice the size of the European Union. ... Since the end of World War II, the economy has achieved relatively steady growth, low unemployment and inflation, and rapid advances in technology. ... The US has the most technologically powerful economy in the world, with a per capita GDP of $\$ 54,800$. In 2014, however, US GDP ran second to China's, when compared on a Purchasing Power Parity basis; the US lost the top spot, where it had stood for more than a century. In the US, private individuals and business firms make most of the decisions, and the federal and state governments buy needed goods and services predominantly in the private marketplace" (The World Factbook, 2015).

An important role is played by the secondary mortgage market. There are a number of features of the structure and operation of the secondary mortgage market of the USA. They are specified by it securities sell, guaranteed by the pledge of real estate.

It is commonly understood that "real estate is the modern term for land and anything that is permanently affixed to it. Fixtures include buildings, fences, and things attached to buildings, such as plumbing, heating, and light fixtures" (Legal Dictionary, 2015).

Firstly, appeared the mortgage market, and only later, after 1970, through the work of "Ginnie Mae", began the practice of issuing securities backed by mortgage assets. At the initial stage of formation of the secondary mortgage market, banks and organizations regularly faced the lack of liquidity for lending for such long-term period, as required by the mortgage. This situation has given rise to the need to refinance loans for housing. Such refinancing was able to provide with the founded by federal government agency "Fannie Mae". It solves this problem by buying debt from banks and savings and loan associations. This allows banks to obtain real money needed for its own functioning, and put the burden of the credit and default risks on the agency.

Then the turnover of securities, backed by a pool of mortgages, began to develop. These tools of the secondary mortgage market have caused the greatest interest among long-term investors. Among these were often insurance companies, pension and trust funds. Of course, the deals with such papers were one of direct interests of the credit agencies. Furthermore, the purchase of mortgage-backed securities for many of them provided an alternative to the original mortgage loans, which required additional costs for insurance and underwriting. Savings and loan associations showed the biggest interest in securities transactions, guaranteed by pools of 
mortgages. It became apparent soon, that for mortgage commitments fell a very substantial part of the long-term investments at the national level. Securities market began to suffer from ever-increasing influence from the mortgage instruments.

\section{Discussion: The Main Features of the Securities Issued by the Mortgage Agencies}

Mortgage agencies - "Fannie Mae", "Freddie Mac" played crucial role for the functioning of the secondary mortgage market activity. They evolved in its status from government agencies to private mortgage companies with state support. Government mortgage agency "Ginnie Mae" remains also on the significant place in such functioning.

By the mid-1990s., "Fannie Mae" acquired 262 billion USD of mortgage debt liabilities, while the volume of outstanding securities, backed by mortgage loans, exceeded 521 billion dollars (Kopeikin, Stebenev, Skorobogatko, \& Penkina, 1999).

The dynamics of the acquisition is very interesting in terms of a retrospective. Thus, since its inception, and before the start of the 1960s the volume of mortgage loan portfolio, acquired by "Fannie Mae", grew, and then began to decline. By the mid-1960s, the volume of the portfolio has decreased in connection with their sale of a significant amount (1.5 billion US dollars). Gradually the volumes of loans purchased by "Fannie Mae" declined relative to the first period of its operation, which was caused by the development of the credit and investment markets, as well as the emergence of new mortgage companies.

"Fannie Mae" emitted the broad range of different debt instruments, secured by a mortgage. It is not accidental circumstance in the activities of this organization - a wider is such specter, the higher is the degree of satisfaction of various investors. In addition, the diversification of the various tools allows the agency to allocate and to hedge the risks of indebtedness better.

Let's consider the basic characteristics of the securities emitted by "Fannie Mae".

First, "Fannie Mae" commitments should be taken in the credit markets as the US securities, issued by a government agency. This rank is directly fixed in the founding documents of "Fannie Mae".

Second, the sale of "Fannie Mae" securities is carried out in a certain period in accordance with the monthly plan agreed with the US Treasury. The federal treasury ensures, that they conducted auctions to sell its own bonds and debentures organizations are supported by the state, not in conflict with the largest sell-debt itself, "Fannie Mae".

Third, "Fannie Mae" may, with the approval of the US Treasury Department, obtain additional loans finance specific programs, if the market is able to absorb the additionally issued securities.

Fourth, "Fannie Mae" freed from the obligation to make registration of the issue in Commission on Securities and Exchange Commission, as well as from executing settlements through the banks of the US Federal Reserve.

Fifth, "Fannie Mae" is entitled to receive an unlimited amount of investment from national banks.

It is difficult to overestimate the value of the given list of emission rights of "Fannie Mae". The collection of these rights contributed to financial stability of "Fannie Mae" for a long time. Prices for its securities only to a small extent were different with the price curve of US Treasuries bonds (Sharfman, 1995).

\section{3. "Fannie Mae": The Main Types of Equity Securities (Debt Instruments)}

"Fannie Mae" produces the following negotiable instruments

1) Short-term (with a period of up to one year) zero-coupon bonds, placed at a discount from face value;

2) medium and long-term bonds with a fixed coupon;

3) medium and long-term bonds with a fixed coupon redeemable;

4) bonds redeemable coupon rate which increases to a certain value at specified intervals (callable step-up notes);

5) various types of so-called structured bonds (structured notes), the coupon rate or the amount of principal repayments, which are tied to a particular index;

6) subordinated debt (Kopeikin, Stebenev, Skorobogatko, \& Penkina, 1999).

Let us consider the characteristics of these types of securities.

Firstly, "Fannie Mae" emits short discount bonds. Maturity varies from 30 to 270 days. According to its characteristics such commitments are close to commercial paper. The yield on them is announced publicly and saved until the next such declaration. Most often, these bonds are purchased by private companies, as well as by 
local authorities and executive authorities.

The second type of securities is medium- and long-term commitments. Term to maturity is between 3 to 25 years. For such securities are set lower limits of the value of a single purchase is (depending on the type of securities) between 10 and 50 thousand dollars. Such large amount is explained by the desire to avoid the purchase of securities by private persons, traditionally storing their savings on accounts of save and loan organizations.

The third type of securities is subordinated bonds (debenture). In this context, they are convertible into other securities, such as shares of the "Fannie Mae". The possibility of conversion creates the potential to increase equity to the issuer. These securities represent unsecured bonds, the holder of which claims the right of a general creditor of all assets of the Issuer in respect of which has not been specifically stated, that they are used as collateral for other debt instruments.

Despite the absence of a specific provision, a certain status and ties to the government give securities issued by "Fannie Mae", high credit ratings, and investor loyalty (USA mortgage market experience: collection of materials, 1995).

The maximum size for the set of the possible borrowing for "Fannie Mae" is determined by the Department of Housing and Urban Development. The calculations are made on the basis of the financial statements, especially on equity, net income and the cost of subordinated convertible bonds. Regarding the latter, the maximum amount is also set. For example, in 1972, "Fannie Mae" had the right to borrow \$25, counting on every dollar of equity and subordinated convertible bonds could be emitted at the rate of $\$ 2$ for each $\$ 1$ ordinary share.

Generally speaking, the issue of ordinary shares is not the largest source of funding for the "Fannie Mae". However, organizations that service "Fannie Mae" loans are obliged to purchase a certain number of such shares. As a rule, such separate obligation of purchase is equivalent to $0.25 \%$ of the outstanding loans on the balance of the service organization. At the same time, "Fannie Mae" gets a certain part of the financing at the expense of providing a variety of services, including underwriting and advisory. Moreover, after the expansion of the areas in which the corporation can act as a private investor, significantly increased the income from such investment. Of course, funding may be involved due to the sale of securities in the portfolio.

\section{4. "Fannie Mae": The Purchase of Mortgage Loans by the Free Market System}

The acquisition of mortgage loans carried out by "Fannie Mae" in accordance with the system of the free market. It is believed that the program promotes the use of all the advantages, that the market situation has folding. This system adopted in 1968, and was originally used only in pricing and determination of the conditions of purchase loans, guaranteed by the authorized government agencies. After the "Fannie Mae" was able to include in its portfolio the loans without guarantee, on their purchase was also spread "the free market system".

Among all mortgage loans there were about $70 \%$ of typical ones. "Fannie Mae" carries out the purchase of credits, the size of loans that can be up to $95 \%$ of the cost of purchased housing. However, there is a condition, that the amount in excess of $80 \%$ must be insured against credit risk or is the agreement under which the seller of the loan will be required to buy it back in the event of default by the borrower. We also establish a limit on the size of the acquired loans. So, in 2000, the maximum amount was $\$ 252700$.

"Fannie Mae" experts usually make sure that all of the proposed loans meet the high standards of underwriting. In a general sense, it means the procedure for lender assessing the probability of repayment of the loan by the borrower and co borrower. The procedure involves underwriting review and analysis of the solvency of the buyer of real estate with the mortgage loan. Among other things, "Fannie Mae" underwriting standards include a maximum ratio of payments to income, ratio of the maximum loan amount to the value of the property and the maximum amount of the loan. Loans which excesses the maximum value and not suitable for the definition "relevant", are called "large loans" ("jumbo loans"). Such loans are purchased by large private corporations. Also, loans, which are fit to all specified standards, are called qualified.

The main feature of the system of free market is rejection of the acquisition of loans by fixed corporation prices. The price is determined through auctions. "Fannie Mae" holds auctions every two weeks, separately for secured and conventional loans.

Auctions are organized in several stages. In the first phase, on the day appointed for the auction, a potential seller of credit reports "Fannie Mae", about the volume of loans and allowed rate of return on them. The rate of income, below which the offer will not be considered, was established by corporation. Future Seller checked for compliance with the criteria. If such compliance is granted, the seller has four months to carry out the sale of all or part of it. "Fannie Mae" contracts with the credit seller are clothed in a standard form. Lending rate is obligatory requisite. Payment is made on the day of delivery of the loan. However, the contracts guaranteed by 
the Housing Authority, payment can be made on the day of conclusion of the contract.

\section{Tandem Program}

Another type of special programs called "tandem program". This type of program includes transactions involving "Ginnie Mae" and provides, that the portion of the loans, acquired by "Ginnie Mae" for a certain period, remains at "Ginnie Mae" "custody" ("stored") or passed to the control of "Fannie Mae" and after that time again redeemed by investors and by the mortgage agencies too. The economic essence of the tandem program is that the purchase of mortgage loans from private lenders, "Ginnie Mae" makes at prices lower than on the market, and sells them to investors at market prices.

When transferring mortgages go under operation of "Fannie Mae", the latter acts as the commissioner and entitled to pay a commission. The amount of remuneration depends on the specific contract. Tandem program used to provide credit resources for low-income families under the state guarantees. At present, the effect of such programs is suspended for an indefinite period.

\section{Conduits: Non-Governmental Mortgage Organizations}

United Nations consider "non-governmental organization (NGO, also often referred to as "civil society organization" or CSO) is a not-for-profit group, principally independent from government, which is organized on a local, national or international level to address issues in support of the public good" (Non-governmental organizations, 2015).

For the purposes of the topic of this article a non-governmental organizations, also often referred to as "conduits", are functioning in the secondary mortgage market. In fact, these legal entities, that buy assets from several sellers, paying for such purchases at the expense of funds received from the securitization and commercial paper secured by mortgage assets.

Among conduits are four main organizations:

1) "Maggie Mae" - Marketing Corporation in the mortgage business. It was established in 1978 and based in Milwaukee, Wisconsin. "Maggie Mae" specializes in transactions with pools of mortgage loans established by the Corporation for insurance guarantee mortgage debt "Mortgage Guaranty Insurance Corporation".

2) "Salomon / RFU" The second largest corporation acts containing conduit "Salomon / RFU", which headquarters is located in Minneanapolis, Minnesota. The company is the successor of the largest and most influential Corporation for housing financing.

3) HOMAK - abbreviation for the Corporation facilitating mortgage companies, created in 1982, as a branch of the National Association of homebuilders. It carries out its activities in the form of a corporation. The members of this association are the developers of this corporation themselves.

\section{Conclusion}

It should be noted that the US experience arouses the particular interest. Since 1970, United States achieved significant results and laid the foundation for the economic development of the United States.

However, a number of scandals related to improper enforcement and active fraudulent actions of a number of officials have occurred in recent years. It has cast a shadow on this industry.

In any civil country of modern globalized world civil society plays a critically important role. Emergence of modern civil society is closely connected with the development of private property which became an incentive for the activity of modern globalized person (Grudtsina, 2013).

Taking into account above, it appears advisable to further development of new regulation mechanisms of a number of organizational and legal issues of the mortgage market, which would be the result of further scientific developments.

Information technology became a part and parcel of most people's daily lives all over the globe (Galushkin, 2015), so it appears to be reasonable to implement new information technologies to make the mortgage market more open and information more accessible for interested persons. Access to such information is subject to the privacy acts, though some information might be made available even to the general public.

\section{References}

Galushkin, A. A. (2015) Internet in Modern Russia: History of Development, Place and Role. Asian Social Science, 11(18), 305. http://dx.doi.org/10.5539/ass.v11n18p305

Grudtsina, L. J., \& Galushkin, A. A. (2013). Questions of modern civil society development in Russian 
Federation. World Applied Sciences Journal, 25(5), 790. http://dx.doi.org/10.5829/idosi.wasj.2013.25. 05.1438

Kopeikin, A., Stebenev, L., Skorobogatko, B., \& Penkina, I. (1999). The American mortgage model. Securities market, 8, 17-22.

Legal Dictionary. (2015). Retrieved from http://legal-dictionary.thefreedictionary.com/real+estate

Non-governmental organizations. (2015). United Nations Rule of Law. Retrieved from http://www.unrol.org/article.aspx?article_id=23

Sharfman, B. (1995). Is Fannie Mae and the US housing finance system: a model for others? Model of the secondary mortgage market: the USA experience (pp. 105-123). Publishing House of the Fund "Institute of Urban Economics".

The World Factbook. (2015). CIA. Retrieved from https://www.cia.gov/library/publications/the-world-factbook/ geos/us.html

USA mortgage market experience: collection of materials. (1995). Benthon.

\section{Copyrights}

Copyright for this article is retained by the author(s), with first publication rights granted to the journal.

This is an open-access article distributed under the terms and conditions of the Creative Commons Attribution license (http://creativecommons.org/licenses/by/3.0/). 